UDC 811.111'42

DOI https://doi.org/10.24919/2308-4863/44-2-18

Olha DUNAIEVSKA,

orcid.org/0000-0002-0915-428X

PhD in Philology, Associate Professor,

Associate Professor at the Foreign Languages Department, Law School of Taras Shevchenko National University of Kyiv (Kyiv, Ukraine) o.dunayevska@gmail.com

Zinaida LEVCHENKO, orcid.org/0000-0002-6831-3543

Teacher of Foreign Languages Department Law School of Taras Shevchenko National University of Kyiv (Kyiv,Ukraine) zlevchenko0405@gmail.com

\title{
FORMING PROFESSIONAL VOCABULARY FOR LAW MAKING
}

The paper addresses the issue of studying a foreign language for specific purposes. The cross-disciplinary character of the paper crystalizes the application of the practices from domains of linguistics, theory of education, and jurisprudence. The research aims at providing the set of the educational tools for enhancing the formation of professional vocabulary for law making. The roles and the functions of both an educator and a learner are specified in the paper in terms of Student-centred model of education. According to the research, an educator undertakes the role of an expert facilitator in the process of acquiring vocabulary for law making, whereas a learner is viewed not as just passive receiver of knowledge but is rather an active and motivated participant of the learning process. The educator is responsible for preparing the platform for implementation the study approach by selecting the methods suitable for development of a motivated learner as a critical thinker in the class, making use of FLIPed learning and Problem-based Learning techniques. The paper determines the acquiring of professional vocabulary for law making as a continuous practice by focusing on four basic elements the teaching should enclose: motivation, opportunities, verification, engagement $(M-O-V-E)$. The online glossary is devised by means of adjusting cognitive-semantic structures for portraying the professional situation in terms of action frames and serves the basis for the above mentioned approach application. Each of four elements has to adhere to the principles of individualistic approach and formation of firm competence; also it has to provide grounds for a life-long education as well as postulate and propagate the continuous professional advancement. What is more, the study offers the universal tools for formation of professional vocabulary regardless of the target language and thus, may be applied to teaching and studying various foreign languages.

Key words: action frame, frame-based vocabulary, FLIPped Learning, Student-centred Approach.

Ольга ДУНАЕВСЬКА, orcid.org/0000-0002-0915-428X кандидат філологічних наук, доцент, дочент кафедри іноземних мов Інституту права Київського національного університету імені Тараса Шевченка (Київ, Україна) o.dunayevska@gmail.com

Зінаїда ЛЕВЧЕНКО, orcid.org/ 0000-0002-6831-3543 викладач кафедри іноземних мов Інституту права Київського національного університету імені Тараса Шевченка (Київ, Україна) zlevchenko0405@gmail.com

\section{ФОРМУВАННЯ ПРОФЕСІЙНОГО СЛОВНИКА ЗАКОНОТВОРЧОСТІ}

Стаття розкриває проблематику вивчення іноземних мов за спеціальним спрямуванням. Міждисциплінарний характер праці експлікує застосування досвіду з галузей лінгвістики, педагогіки та юриспрудениії. Мета роботи - формування набору навчальних засобів, які мають використовуватися для успішного формування професійного словникового запасу зі спеціальності законотворчість. Ролі та функиї як викладача, так $i$ здобувача освіти, специфікуються в термінах студентоцентрованої моделі освіти. Згідно з дослідженням, викладач виконує роль експерта-фасилітатора в процесі оволодіння лексичним запасом, тоді як студент розглядається не як лише пасивний здобувач знань, а як активний та мотивований учасник навчального прочесу. Викладач зобов'язаний підготувати платформу для впровадження обраного ним підходу до навчання, визначаючи методи, які сприятимуть розвитку здобувача освіти як мотивованої та критично мислячої особистості, за використанням методів деполяризованого (перевернутого) та проблемного методів навчання. Робота визначає формування професійного 
словника як тривалу практику та фокусується на виокремленні чотирьох базових компонентів викладання. Онлайн-глосарій формується із застосуванням елементів когнітивної семантики для презентаиії професійних ситуацій за допомогою використання структури акціональних фреймів, щзо слугує підгрунтям для застосування згаданого вище чотирьохелементного підходу. Кожен із чотирьох елементів має відповідати приниипам індивідуалістичного підходу та сприяти формуванню компетентності; також він має створювати підгрунтя для безперервного навчання, постулювати та пропагувати безперервне професійне зростання. Окрім иього, робота пропонує універсальні засоби для формування словникового запасу, незалежно від того, яка мова вивчається, а отже, може застосовуватися у викладанні та вивченні різних іноземних мов.

Ключові слова: акціональний фрейм, вокабуляр на основі фреймового аналізу, деполяризоване (перевернуте) навчання, студентоцентроване навчання.

Articulation of issue. "Communication - the human connection - is the key to personal and career success." The place of communication in building one's career gets transparent in the quote shared by Paul J. Meyer ${ }^{1}$, the billionaire and the founder of the Success Motivation Institute (the frontier of personal development and selfimprovement industry). The wisdom explicated by Paul $\mathrm{J}$. Meyer is relevant to exceling in the overwhelming employment opportunities in general, and in law in particular. Moreover, the author of the quote addresses the very need for effective communication as the decisive tool for career in law articulated by the UK and US leading expert institutions of Western culture as well as by those from India, the bright representative of Eastern culture respectively. This importance of communication factor for career in law is illustrated in the table below.

Grounding on the data provided in Table 1, one can clearly inspect the demand on communicative

Table 1

Communication in Career for Law

\begin{tabular}{|c|c|c|c|}
\hline Expert & Period & Origin & Treatment of communication factor in career for law \\
\hline PROSPECTS $^{12}$ & 2021 & The UK & $\begin{array}{l}\text { Communication is rated as the } 3^{\text {rd }} \text { in the scale of skills } \\
\text { for successful law career }\end{array}$ \\
\hline Harvard Law School ${ }^{3}$ & $\begin{array}{l}\text { attributed to up-to-date } \\
\text { school policy }\end{array}$ & The USA & $\begin{array}{l}\text { Negotiation skills are placed as the priority by emphasizing } \\
\text { such competences as good writing and interpersonal skills } \\
\text { grounding on strong language command }\end{array}$ \\
\hline Sushant University ${ }^{4}$ & 2019 & India & $\begin{array}{l}\text { Verbal communication is rated as No. } 1 \text { or the key skill } \\
\text { to be mastered by a legal professional for successful } \\
\text { counselling, advice, and doing advocacy in court }\end{array}$ \\
\hline
\end{tabular}

skills formation. Furthermore, the foreign language command is treated in almost the same way while acting in international context where Legal English plays the leading part. The simplest example of joining international context is an initial lawyer-client interview, which is usually conducted by a lawyer (often assisted by a paralegal, e.g. a student of a law school) with a lay person who does not speak the lawyer's native language(s). So, the article addresses the up-to-date challenges concerned with vocabulary formation for legal professionals which is one of the hardest issues to tackle while studying any professional language due to the difficulties born by acquiring, exercising, and developing the corpus of professional terms. The research is the intersection point of several disciplines: law, education, and linguistics and thus, it can be categorised as an interdisciplinary investigation compiling the legal education materials and some issues of real legal professional's environment applied as empirical data for linguistic analysis. The question under investigation is of high importance due to the fact that it outlines the combination of human professional activity, learning, and teaching of Legal English vocabulary and the ways of implementing the teaching in university classroom.

\footnotetext{
${ }^{1} \mathrm{http} / /$ pauljmeyer.com/the-legacy/humble-beginnings/
}

Overview of available researches. The attention to teaching language of legal environment was demonstrated by the number of scientist; particularly they covered such aspects as:

- language philosophy and its social impact involving the elements of critical semiotics and rhetoric by P. Goodrich (Goodrich, 1987);

- communicative potential of legal English by P. Tiersma, ${ }^{2}$ L. M. Solan, J. Ainsworth, and R. W. Shuy; ${ }^{3}$

- strategies to apply in multilingual environment by D. $\mathrm{Cao} ;{ }^{4}$

- cooperation of forensic linguist and a trial lawyer by R. W. Shuy; ${ }^{5}$

- lawsuit language and role of a lawyer by O. Dunaievska (Dunaievska, 2020: 35-37);

\footnotetext{
${ }^{2}$ Tiersma P. Legal English. University of Chicago Press. The USA. 1999.

${ }^{3}$ Solam L. A., Ainsworth J., Shuy R. W. Speaking of Language and Law (Edited by Lawrence M. Solan, Janet Ainsworth, and Roger W. Shuy). Oxford University Press. Oxford. UK. 2015.

${ }^{4}$ Cao D. Translating Law. Multilingual Matters Ltd. Clevedon. Buffalo. Toronto. The UK. The USA. Canada. 2007.

${ }^{5}$ Shuy W. R. Linguistics in the courtroom: a practical guide. Oxford University Press. Inc. New York. The USA. 2006
} 
- frame and semantic aspects of legal vocabulary by O. Dunaievska (Dunaievska, 2020(a);

- critical thinking skills in legal profession by S. Živković (Živković, 2016: 102).

Having analysed the researches available, it can be suggested that there is none addressing the formation of professional vocabulary for law making. So, it may be suggested that the vocabulary for law making still remains almost uncovered and the aim of the article is to provide the set of the educational tools enhancing the formation of professional vocabulary for law making through setting the following objectives: to identify the roles / functions of both an educator and a learner in the study process; to individualise the understanding of vocabulary for law making; to set out the opportunities for keeping pace with continuous professional advancement etc.

Statement of basic material. To make the teaching of vocabulary for law making an effective and coherent process which will adhere the requirements of continuous education postulated by The European framework of key competences for lifelong learning ${ }^{6}$ it is necessary to approach the lexical corpus referring to the mentioned domain in well-planned manner. The latter is offered by the four pillared M-O-V-E approach (Dunaievska, 2020 (a): 175) developed for forming vocabulary while teaching English for specific purposes. M-O-V-E is an acronym for unified aspects of vocabulary teaching and learning where: $\mathrm{M}$ signifies MOTIVATION, O - OPPORTINITIES, V - VERIFICATION, E - ENGAGEMENT. Every part of an acronym specifies 4 particular stages of acquiring vocabulary for law: stage $1-$ Motivation; stage 2 -Opportunities; stage 3 -Verification; stage $4-$ Engagement. The stages interact in the way depicted by the construct, which points out the vital importance of treating the vocabulary domain, in our case law making vocabulary, grounding on the frames evoked in particular professional situation. The suggested idea assumes the notion of encountering the situations based either on evoked framing that serves the familiar situations or invoked framing provoked by the events previously unknown (Fillmore, 1982: 20; Dunaievska, 2020 (b) to a learner. So, the task of the educator is to make as many transitions from invoked framing to the evoked one as possible. The principle of a frame-based vocabulary sets the preliminary for undergoing different stages of professional vocabulary development. Also, framebased vocabulary approach enables acquiring of

\footnotetext{
$\overline{{ }^{6}}$ The European framework of key competences for lifelong learning. Mode of Access: https://ec.europa.eu/education/education-in-the-eu/council-recommendation-on-key-competences-for-lifelong-learning_en
}

professional vocabulary to become an individualised process where each learner gets the understanding of their role in the professional environment as well as associates the particular terms and notions with the situations they may be used in.

Frame-based vocabulary for law gets constructed through utilising the method of frame semantics introduced by S.A. Zhabotynska (Zhabotynska, 2010) that assumes the operation with possible legal career events through using the action frame structure: $\mathrm{WHO}-$ ACTS (on) - WHO / WHAT. Pertaining to the career in law making, there is an unlimited number of action frames depicting the situation the law maker may encounter. One can provide the situations ${ }^{78910}$ of law drafting, passing the law; amending the law; verifying the law and repealing the law as examples for being learnt through action frames under the same names:

1) Action frame "LAW DRAFTING": WHO (a law drafter) - ACTS (drafts) - WHAT (the law);

2) Action frame "PASSING THE LAW": WHO (the legislative body) - ACTS (passes) - WHAT (the law);

3) Action frame "AMENDING THE LAW": WHO (the expert committee) - ACTS (amends) WHAT (the law);

4) Action frame "VERIFYING THE LAW": WHO (Venice Commission) - ACTS (reviews) WHAT (the law);

5) Action frame "REPEALING THE LAW": WHO (the legislative body) - ACTS (repeals) WHAT (the law).

The offered frames consist of the slots WHO, ACT(on), WHAT filled with the lexical material and can be approached as the containers for vocabulary pertaining to the particular participant of the situation as well as for their actions. For example, the slot WHO of action frame "LAW DRAFTING" contains the lexis: lawyers, editors, clerks, bill's sponsor, fronter etc; the slot ACTS contains the lexis: to research the Constitution; to research the precedents available to draft; to consult the committee; to propose the law to

${ }^{7}$ Second edition [Electronic Recourse]. International Institute
for Democracy and Electoral Assistance. 2017. Mode of Access:
https://www.idea.int/sites/default/files/publications/what-is-a-
constitution-primer.pdf
${ }^{8}$ Guide to Legislation and Legislative Process in British Columbia
[Electronic Recourse]. Mode of Access: https://www.crownpub.
bc.ca/Content/documents/2-DraftingPrinciples_August2013.pdf
${ }^{9}$ Compilation of Venice Commission Opinions and Reports on
Law-Making Procedures and the Quality of Law [Electronic
Recourse] European Commission for Democracy Through Law
(Venice Commission) Strasbourg, 29 March 2021. Mode of
Access: https://www.venice.coe.int/webforms/documents/?pd-
f=CDL-PI(2021)003-e
${ }^{10}$ The Legislator's Hanbook [Electronic Recourse]. New Jer-
sey Legislature. Office of Legislative Services. Mode of Access:
https://www.njleg.state.nj.us/legislativepub/legislator_handbook.pdf 
the legislative body etc.; the slot WHAT contains: the rules, the regulations, the legislative acts, the bills etc. The content of the slot depends on the peculiarity of the study material the educator uses in the classes. This is the function of an educator to prepare the glossary for the student of the course beforehand and give an access to it through tools available. The effective tool is a glossary sheet elaborated through google document the excess to which is shared with the learners.

When the frame-based vocabulary is formed and the glossary for the course is available for every learner it is high time to design the principles of acquiring the vocabulary through the course by using $\mathrm{M}-\mathrm{O}-\mathrm{V}-\mathrm{E}$ approach concerning the definite role and functions of the educator. The application of M-O-V-E presupposes the usage of Student-centred Learning (SCL) paradigm. ${ }^{11}$ The latter postulates the equal accessibility to the source of knowledge where both a student and an educator have levelled opportunities in accessing the study material, but an educator, being a facilitator, is navigating a learner for the latter not to lose the focus on prime things and to filter the deceiving facts out. So, the educator plays the role of a facilitator, supervisor and advisor but in any case is the only source of information; the facilitator's function is to sort out the material in adequate portions, to verify the data offered by the learner and to orange the comfortable climate for learning by using appropriate teaching approaches fitting SCL paradigm. The first of 4 stages of M-O-V-E approach is supplied by motivation. "The environment created by Modern European Higher Education Area (EHEA) in 1999 has introduced the principles of transparency, mobility, and great emphasis on the learners as proactive ones, opening new horizons for motivated students to become the core of modern system of education." (Dunaievska, 2020(a): 35-37). The learners are given freedom of choice in courses they enrol into. Moreover, the decision made on the course is not biased as thus responds the very individual needs and cravings of the motivated learners. To check and evoke the motivation the educator may use the motivation essay when inspecting the motivation issue. The development of communicative skills in Legal English as Foreign Language classes requires the adaptation to approaching a modern learner from the standpoint of an active participant and a motivated explorer of information.

The acquiring of professional vocabulary for law making requires the awarding of special attention to application of methods to provoke their students to

\footnotetext{
${ }^{11}$ Brandes D., Ginnis P. A Guide to Student-centered Learning. Oxford. Blackwell. 1986.
}

think rather than to passively perceive the educational material. In other words, the students are awarded with opportunities to be proactive in mastering their career. This set of techniques undermines the grounding for the next pillar of M-O-V-E - Opportunities. The stage encompasses the variety of methods / technics for acquiring the vocabulary for law making e.g. Problem-based, Project and FLIPped Learning, due to their focus on development of critical thinking in a modern student of law - proactivity and problem solving features, bring to the classrooms the techniques underlining the creativity. The method of a "flip" is an extremely productive teaching instrument in active learning: a learner is provided by a mentor rather than by a teacher "by his side." ${ }^{12}{ }^{13}$ Accordingly, the learners are instructed to familiarise themselves with the study material before the class and, in fact, are free to do their own research in their own pace with the media to their taste (e.g. accompanied by the music / in a quiet place / listening to the podcasts or watching the video records). This turns out to be particularly valuable while having a remote mode of education when a learner earns an opportunity to be an active user of their background knowledge and acquires skills in this process. Moreover, the glossary provided by the educator while commencement of the course gets continuously enriched and extended by each student individually, and becomes their rather valuable asset.

Upon the completion of English for law making course the glossary developed and the vocabulary acquired remains intensively used and is constantly edited while encountering the situations modelled by the lecturers, participating in workshops and doing research. Furthermore, the educator is obliged to remind the learner on the options of volunteering at the university law clinic and assisting the legal professionals with their foreign visitors or by starting the career of a clerk in legislative body. All these options for practicing the professional vocabulary for law are called verification stage, where the learner can try and check the command on the lexis acquired while the course. The learners obtain the opportunity to extend their vocabulary on spot by adding the newly encountered and previously unknown lexis to their glossary lists hence it being kept in the Google Document with $24 / 7$ access. Finally, the learners are highly recommended to join the professional communities for law drafters to enable

\footnotetext{
${ }^{12}$ Baker J. W. The "Classroom Flip": Using Web Course Management Tools to Become the Guide on the Side. In: the 11th International Conference on College Teaching and Learning: Jacksonville. Florida. 2000.

${ }^{13}$ Bergmann J., Sams. A. Flip Your Classroom: Reach Every Student in Every Class Every Day. International Society for Technology in Education. ISTE and ASCD. 2012.
} 
the continuous enrichment of their professional vocabulary through engagement into the activities and projects of the community. This will form the last stage - engagement in the foreign professional environment which opens the horizons for continuous advancement of vocabulary.

Conclusions. The building of professional vocabulary for law making is facilitated through application of M-O-V-E approach utilised by an educator. The process of acquiring professional vocabulary through $\mathrm{M}-\mathrm{O}-\mathrm{V}-\mathrm{E}$ requires the identifying a learner as a motivated and active receiver and compiler of information and vocabulary on law making. Also, to the functions of a learner belong continuous enrichment and extension of the professional vocabulary, primarily acquired through English for law making course. The educator acts as a facilitator and the utmost expert in the domain under study. Performance of an educator includes selection of the study material, formation of the corpus of vocabulary necessary for learners to comfortably learn and understand the process of law making. Moreover, an educator selects the best of the opportunities available: methods and tools corresponding the principles of Student-centred Learning Paradigm. The frame-based approach to forming the stock of vocabulary and the application of FLIPped Learning are the prerequisites to individualisation of the study process in general and learning professional vocabulary for law making in particular. While using the opportunities for practicing the vocabulary acquired, the learner verifies it in both modelled and real career situations for keeping pace with continuous professional advancement.

\section{BIBLIOGRAPHY}

1. Goodrich P. Legal Discourse. Studies in Linguistics, Rhetoric and Legal Analysis. Palgrave Macmillan, UK. 1987.

2. Dunaievska O. V. Function of a Lawyer: Frame Approach. Science and Education a New Dimension. Humanities and Social Sciences. Vol. VIII(37). 2020. P. 35-37. DOI: 10.31174/SEND-HS2020-223VIII37-08. Mode of Access: https:// seanewdim.com/uploads/3/4/5/1/34511564/hum viii 223 37.pdf (accessed 20 November 2021).

3. Dunaievska O. Professional Communication: from Frame Semantics to Learning Environment. Scientific Developments of European Countries in the Area of Philological Researches: Collective Monograph. 2020 (a). Riga: Izdevnieciba "Baltija Publishing." Part 1. P. 35-37. DOI: 10.30525/978-9934-588-56-3.1.10

4. Dunaievska O. Modifying "Breaking Bad News" Communication: Cross-Cultural and Cognitive-Semantic Approaches/Dunaievska O., Chaiuk T. Academic JournalofInterdisciplinary Studies. RichtmannPublishingLTD.2020(c). Italy. № 9 (2): 1-14. DOI: 10.36941 /ajis-2020-0017

5. Zhabotynska S. Principles of building conceptual models for thesaurus dictionaries. Cognition, communication, discourse. International On-line Journal. 2010. Vol. 1. P. 72-92. DOI: 10.26565/2218-2926-2010-01-0. Access Mode: http://sites.google.com/site/cognitiondiscourse/vypusk-no1-2010 (accessed 29 January 2021).

6. Živković S. A Model of Critical Thinking as an Important Attribute for Success in the 21st Century. Procedia - Social and Behavioral Sciences. 2016. Vol. 232. P. 102. DOI: 0.1016/j.sbspro.2016.10.034. Mode of access: https://core.ac.uk/download/pdf/82491079.pdf (accessed 15 November 2021).

\section{REFERENCES}

1. Goodrich P. Legal Discourse. Studies in Linguistics, Rhetoric and Legal Analysis. Palgrave Macmillan, UK. 1987.

2. Dunaievska O. V. Function of a Lawyer: Frame Approach. Science and Education a New Dimension. Humanities and Social Sciences. Vol. VIII(37). 2020. P. 35-37. DOI: 10.31174/SEND-HS2020-223VIII37-08. Mode of Access: https://seanewdim.com/uploads/3/4/5/1/34511564/hum_viii_223_37.pdf (accessed 20 November 2021).

3. Dunaievska O. Professional Communication: from Frame Semantics to Learning Environment. Scientific Developments of European Countries in the Area of Philological Researches: Collective Monograph. 2020 (a). Riga: Izdevnieciba "Baltija Publishing." Part 1. P. 35-37. DOI: 10.30525/978-9934-588-56-3.1.10

4. Dunaievska O. Modifying "Breaking Bad News" Communication: Cross-Cultural and Cognitive-Semantic Approaches/Dunaievska O., Chaiuk T.Academic Journal ofInterdisciplinary Studies. Richtmann Publishing LTD.2020(c). Italy. № 9 (2): 1-14. DOI: 10.36941/ajis-2020-0017

5. Zhabotynska S. Principles of building conceptual models for thesaurus dictionaries. Cognition, communication, discourse. International On-line Journal. 2010. Vol. 1. P. 72-92. DOI: 10.26565/2218-2926-2010-01-0. Access Mode: http:// sites.google.com/site/cognitiondiscourse/vypusk-no1-2010 (accessed 29 January 2021).

6. Živković S. A Model of Critical Thinking as an Important Attribute for Success in the 21st Century. Procedia - Social and Behavioral Sciences. 2016. Vol. 232. P. 102. DOI: 0.1016/j.sbspro.2016.10.034. Mode of access: https://core.ac.uk/download/pdf/82491079.pdf (accessed 15 November 2021). 